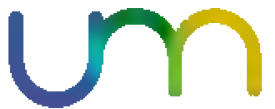

The Learning

University

\title{
THE CONTENT OF METAL ELEMENTS IN MEDICINAL PLANTS IN DUSUN MESU DESA BOTO JATIROTO WONOGIRI CENTRAL JAVA INDONESIA
}

\author{
Arum Suproborini, Universitas PGRI Madiun \\ M.S.Djoko Laksana, UPN Veteran Yogyakarta \\ Dwi Fitri Yudiantoro, UPN Veteran Yogyakarta \\ Email: arum.suproborini15@gmail.com
}

\begin{abstract}
This study aims to determine the content of elements of $\mathrm{As}, \mathrm{Hg}, \mathrm{Mn}$, and vegetation analysis of medicinal plants. The research method used is survey method. Crop sampling using purposive random sampling method. Crop samples analyzed the content of As, $\mathrm{Hg}$, and Mn by XRF method. The analysis was conducted on 6 types of medicinal plants. The results of XRF analysis showed that soil and plant samples contain high As, $\mathrm{Hg}$, and Mn elements.
\end{abstract}

Keywords: medicinal plants, metal elements, vegetation analysis

The research area is morphologically included in the form of volcanic hill land with an average slope of $30^{\circ}$, temperatures ranging from $24-32^{\circ} \mathrm{C}$ with an average rainfall of $1.845 \mathrm{~mm} /$ year

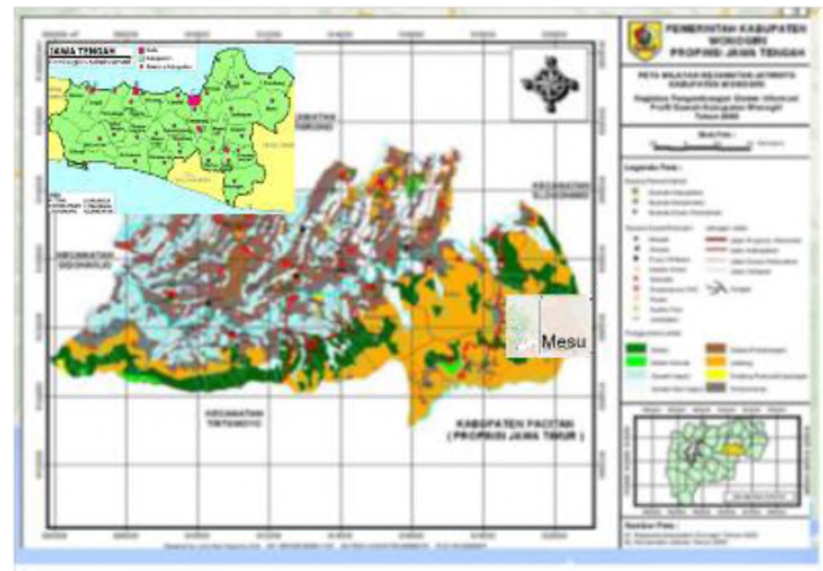

Figure 1. Map of Research Locations

Abissalam, et al. (2009), explains that based on an integrated study that includes geomorphology, stratigraphy, geological structure, petrology, alteration, and mineralization shows that this region is a fossil of ancient volcanoes. This ancient volcano was formed on the ocean floor and is part of the volcano archipelago arches. The interaction between magma, hydrothermal fluid and surrounding rocks leads to alteration and mineralization in facies of the volcano center. The mineralization process produces metal elements such as $\mathrm{Fe}, \mathrm{Mn}, \mathrm{Cu}, \mathrm{Pb}, \mathrm{Hg}, \mathrm{As}, \mathrm{Zn}, \mathrm{Ag}$, and other metal elements (Putranto, 2011). The content of metal elements in nature can affect the existing vegetation. Vegetation is defined as the whole plant of an area consisting of herbs, shrubs, trees that live together somewhere, interacting with each other and with their environment 


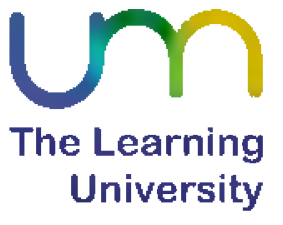

Icssh, 1(1), 2017

PROCEEDINGS

The Ist International Conference on Sports Science and Health

(Agustina, 2008; Maryantika et al., 2010, Susanto, 2012). One type of vegetation planting plant is a medicinal plant. The definition of medicinal plants in botanical is a plant that can be used as medicine (roots, stems, leaves, flowers). Utilization of medicinal plants can be boiled by drinking water or extracted. The existence of medicinal plants is very important for the local community.

Heavy metal is a high molecular weight metal element. In low levels heavy metals are generally already toxic to plants and animals, including humans. Including heavy metals that often contaminate habitat are $\mathrm{Hg}, \mathrm{Cr}, \mathrm{Cd}, \mathrm{As}$, and $\mathrm{Pb}$. Heavy metal is a natural component of the soil. This element can not be degraded or destroyed. Heavy metals can enter into the human body through food, drinking water, or air. Heavy metals such as copper, selenium, or zinc are needed by the human body to help the body's metabolic performance. However, it can potentially become toxic if the concentration in the body is excessive. Heavy metals become dangerous due to the bioaccumulation system, which increases the concentration of chemical elements in living organisms.

Plants containing mercury when consumed can accumulate in the body. Mercury usually enters the human body through digestion. When there is more accumulation, it can result in degeneration of nerve cells in the cerebellum that control the nervous condition, disruption to the wide view, degeneration of the neural membrane and small brain parts. This element can be mixed with enzymes in the human body causing the loss of enzyme's ability to act as a catalyst for important body functions (Setiabudi, 2005). Death of a plant species can reduce the diversity of vegetation types in a landform. The diversity of plant species shows the diversity or variety of flora species from the lower growth, seedling, stake, pole, and tree (Syafei, 1990). Species diversity can be used to measure community stability, ie the ability of a community to keep itself stable despite disturbances to existing vegetation. According to Arrijani (2008), in general the presence of vegetation in a land form has a positive impact on the balance of ecosystems. Based on the above description, the purpose of this study is to determine the content of metal elements to the diversity of medicinal plants and their impact on human health.

\section{METHOD}

The research method used is survey method (observation, measurement), and laboratory analysis. In the crop sampling using purposive random sampling method. This method is done by plot plot using wooden and raffia pathok with the size of plot for seedling, stake, pole, and tree respectively is $2 \times 2 \mathrm{~m} ; 5 \times 5 \mathrm{~m} ; 10 \times 10 \mathrm{~m}$; and20x20m. Positioning and observation plot with GPS (Geographic Position System). Soil acidity level was measured using Soil Tester Takemura Eletric Works LTD. The mercury content of the soil was measured using Mercury Survey Meter Brand NIC model EMP-2. Plants found in each observation plot were recorded by species name and number, measured stem diameter at breast height $(1.3 \mathrm{~m})$, and samples of plants wrapped with aluminum foil were labeled and then analyzed the content of As, $\mathrm{Hg}$, and Mn with XRF (X- Ray Flourecence) at XRF Laboratory Faculty of Earth Science and Technology Bandung Institute of Technology. The collected vegetation data were analyzed for diversity index using Muller-Dombois and Ellenberg (1974)

\section{RESULTS}

\section{The content of soil mercury and soil Ph}

The results of the measurement of mercury content on the soil ranged from 0.001 to $0.044 \mathrm{mg} / \mathrm{m}^{3}$ and soil $\mathrm{pH}$ ranged from 4 to 6.8 
Table 1. The content of soil mercury and soil Ph

\begin{tabular}{|c|c|c|c|c|}
\hline \multirow[t]{2}{*}{ No } & \multirow[t]{2}{*}{ Location } & \multirow[t]{2}{*}{ Soil pH } & \multicolumn{2}{|c|}{ Soil Hg } \\
\hline & & & $\left(\mathrm{mg} / \mathrm{m}^{3}\right)$ & (ppm) \\
\hline 1. & $\operatorname{Tn} 1$ & 6,0 & 0,004 & 0,000004 \\
\hline 2. & Tn. 2 & 5,0 & 0,021 & 0,000021 \\
\hline 3. & Tn. 3 & 4,6 & 0,004 & 0,000004 \\
\hline 4. & Tn. 4 & 4,8 & 0,001 & 0,000001 \\
\hline 5. & Tn. 5 & 4,8 & 0,002 & 0,000002 \\
\hline 6. & Tn. 6 & 6,2 & 0,002 & 0,000002 \\
\hline 7. & Tn. 7 & 5,9 & 0,019 & 0,000019 \\
\hline 8. & Tn. 8 & 4,5 & 0,036 & 0,000036 \\
\hline 9. & Tn. 9 & 5,0 & 0,003 & 0,000003 \\
\hline 10. & Tn. 10 & 6,6 & 0,002 & 0,000002 \\
\hline 11. & Tn. 11 & 5,2 & 0,044 & 0,000044 \\
\hline 12 . & Tn. 12 & 5,8 & 0,001 & 0,000001 \\
\hline 13. & Tn. 13 & 4,4 & 0,036 & 0,000036 \\
\hline 14. & Tn. 14 & 4,8 & 0,001 & 0,000001 \\
\hline 15. & Tn. 15 & 5,7 & 0,004 & 0,000004 \\
\hline 16. & Tn. 16 & 6,2 & 0,003 & 0,000003 \\
\hline
\end{tabular}

Description: $1 \mathrm{mg} / \mathrm{m}^{3}=1 / 1000 \mathrm{ppm}$

The content of Mn, As, and Hg on Medicinal Plants

Result of analysis of Mn, As and $\mathrm{Hg}$ content of medicinal plants at study sites

Table 2. Content of Mn, As, and Hg medicinal plants

\begin{tabular}{clccc}
\hline No. & \multicolumn{1}{c}{ Species } & Mn $(\%)$ & As $(\%)$ & Hg $\mathbf{( \% )}$ \\
\hline 1. & Eugenia aromatica & 0,1143 & $<0.0001$ & $<0,0001$ \\
2. & Carica papaya & $<0,0001$ & $<0,0001$ & $<0,0001$ \\
3. & Curcuma domestica & 0,0089 & $<0,0001$ & $<0,0001$ \\
4. Eugenia aperculata & 0,0057 & $<0,0001$ & 0,0149 \\
5. Leucaena glauca & 0,0102 & $<0,0001$ & 0,0131 \\
6. & Zingiber officinale & 0,0176 & $<0,0001$ & 0,0095 \\
\hline
\end{tabular}

Description: $1 \%=10,000 \mathrm{ppm}$

Based on the results of analysis of $\mathrm{Mn}$, As and $\mathrm{Hg}$ content in 6 species of medicinal plants (Table 2) showed Mn content ranges from $<0.0001-0.1143 \%$. The highest content of Mn found in Eugenia aromatica plant is $0,1143 \%$. As $<0.0001 \%$ content in all plant species. $\mathrm{Hg}$ content ranges from $<0.0001-0.0149 \%$. The highest content of $\mathrm{Hg}$ is found in Eugenia aperculata which is 0,0149\%.

\section{Diversity of Medicinal Plants}

At the observation of vegetation at the location of the study found 6 types of medicinal plants as many as 144 individuals at the growth rate of seedlings, piles, poles, and trees. Calculation results of the medicinal plant diversity at seedling, stake, pole, and tree level in the study sites

Table 3. Diversity Index (H1) of Medicinal Plants at seedling, stake, pole, and tree

\begin{tabular}{llll}
\hline No. & & Growth Rate & $\mathbf{H}^{1}$ \\
\hline 1. & Seeds & 0,68255 & \\
2. & Shurbs & 0,86759 & \\
3. & Poles & 0,57832 & \\
4. & Trees & 0,56233 & \\
\hline
\end{tabular}


Based on calculation of index value of diversity $(\mathrm{H1})$ at seedling level, stake, pole, and tree (Table 3) ranged from $0.56233-0.86759$ is low.

\section{Composition of Diversity of Medicinal Plants}

The composition of plant medicinal diversity in the study sites consisted of Eugenia aromatica, Carica papaya, Curcuma domestika, Eugenia aperculata, Leucaena glauca, and Zingiber officinale

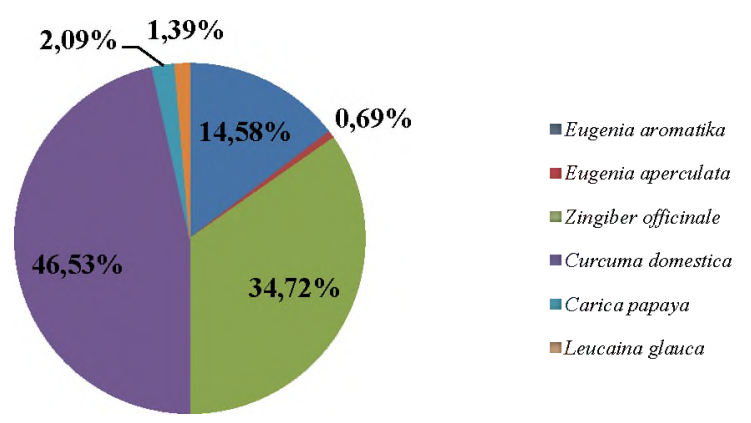

Figure 2. Composition of Diversity of Medicinal Plants

Based on the calculations (Figure 3), the highest sequence of composition of medicinal plants was Curcuma domestica $46.53 \%$, Zingiber officinale $34.72 \%$, Eugenia aromatica 14.58\%, Carica papaya 2.08\%, Leucaena glauca 1, 39\%, and Eugenia aperculata $0.69 \%$.

\section{DISCUSSION}

\section{The content of soil mercury and soil pH}

According to Mirdat et al. (2013) soil mercury content is strongly influenced by soil $\mathrm{pH}$. The mercury content of the soil at the study site is still below the threshold due to less than $0.5 \mathrm{ppm}$. This is in accordance with the opinion of Alloway and Ayres (1995) which states that the mercury content in the soil is said to exceed the threshold that is when more than $0.5 \mathrm{ppm}$. The low mercury content at the study site may be due to the low clay content of the soil. This is in accordance with the opinion of Alloway (1990) which states that clay fraction is an important soil properties in absorbing metallic elements. it is also affected by soil $\mathrm{pH}$ (Stennis, 1990).

The low low Hg content in the soil according to Fardiaz (1992) is also due to most of the heavy metal $\mathrm{Hg}$ disappearing from the soil, as it undergoes methylation into the form of volatile molecules and undergoes volatilization. Methylation is usually performed by anaerobic microorganisms and can also be associated with organic acids. Methylation is the transformation of inorganic mercury into methylated organic mercury by the activity of anaerobic microorganisms.

\section{The content of Mn, As, and $\mathrm{Hg}$ on Medicinal Plants}

The mercury content in medicinal plants is high $(<0.0001 \%-0.0149 \%)$ has crossed the threshold. This is in accordance with the opinion of Alloway and Ayres (1995) which states that the mercury content in the plant should be no more than $0.5 \mathrm{ppm}$. Six types of perennials found in the research sites belong to hyperlolerant plants. This is 
in accordance with Widyati's opinion (2011) which states that a plant is said to have hyperolinary properties if the plant can thrive without undisturbed growth, because the plant has the ability to accumulate and translokasi heavy metals including mercury so that the growth of roots and buds does not experience obstacles. The content of mercury in Eugenia aperculata, Leucaena glanca, and Zingiber officinale is more than $10 \mathrm{ppm}$ so that the plants are grouped in hyperacumulator plant group. This is in accordance with the opinion of Hadiani (2009), which states that mercury hyperacumulator plant is a plant that can accumulate mercury metal in a concentration of $10 \mathrm{ppm}$.

The content of $\mathrm{Mn}$ and As in medicinal plants in the study sites is also quite high. The high content of $\mathrm{Mn}, \mathrm{As}$, and $\mathrm{Hg}$ in these medicinal plants is probably due to the fact that the plant is a long-grown alteration area containing Mn, As, and Hg. Widyati (2011) states that the number of metal elements absorbed by plants depends on the type and age of the plant. It is also caused by environmental conditions, water content and nutrients at these locations that are used for the growth and development of these types of plants.

\section{Diversity of Medicinal Plants}

The low level of diversity $\left(\mathrm{H}^{1}\right)(0.56233-0.86759)$ (Table 6), indicates that the medicinal plant communities in the study sites have unstable levels of unstable species stability. This is probably due to environmental conditions, water content and nutrients in the soil is less able to support the growth and breeding of these plants. High species diversity shows that the community has a high complexity, because the interaction of species occurring within the community is very high. Communities are said to have low species diversity, if the community is composed by few species and if only a few species predominate (Indriyanto, 2008).

\section{Composition of Diversity of Medicinal Plants}

The highest composition of medicinal diversity was Curcuma domestica $46,53 \%$, Zingiber officinale $34,72 \%$, Eugenia aromatica $14,58 \%$, Carica papaya $2.08 \%$, Leucaena glauca 1,39\%, and Eugenia aperculata 0, 69\%. Curcuma domestica and Zingiber officinale have high growth rates. This is due to several factors: the environment, the water content and nutrients in these locations strongly support the growth and proliferation of these plants.

\section{Impact of Mn, As, and $\mathrm{Hg}$ Content On Medicinal Plants Against Human Health}

In low levels heavy metals are generally already toxic to plants and animals, including humans. Heavy metals become dangerous due to the bioaccumulation system, which increases the concentration of chemical elements in living organisms. Heavy metals can enter into the human body through food, drinking water, or air. The effect of $\mathrm{Mn}, \mathrm{As}$, and $\mathrm{Hg}$ on human health (Widowati et al., 2008), as follows:

\section{Manganese (Mn)}

$\mathrm{Mn}$ is an essential micronutrient for humans, plants and animals. Mn toxicity usually occurs through inhalation exposure with symptoms of permanent interference of the extrapyramidal nervous system, psychiatric disorders and cirrhosis of the liver.

\section{Arsenic (As)}

As micronutrients are needed by living things, but use in large doses is toxic. As is carcinogenic, mutagenic and teratogenic. Peroral exposure may increase the risk of skin cancer, lung, bile, liver, kidney and prostate, while through inhalation can cause lung cancer. Non-cancer toxicity of As includes thickening skin, skin discoloration, stomach pain, vomiting, diarrhea, numbness of hands and feet, partial paralysis and blindness. Mercury (Hg) 
Un

The Learning University

Hg forms that enter into the environment include: (1) Inorganic hg derived from rainwater or river flow and is stable at low $\mathrm{pH}$. Inorganic $\mathrm{Hg}$ compounds, such as $\mathrm{Hg}$ (NO 3). (2) $\mathrm{HgCl} 2$ and $\mathrm{HGO}$ will be accumulated in liver, kidney and brain organ. The inorganic $\mathrm{Hg}$ toxicity includes nervous system disorders, such as tremor, tooth failure and loss, anemia, albuminuria, and other symptoms of kidney damage and intestinal mucosal damage. (3) Organic hg such as phenyl mercury $(\mathrm{C} 6 \mathrm{H} 5-\mathrm{Hg})$, metal mercury $(\mathrm{CH} 3-\mathrm{Hg})$ which can come from agriculture that is pesticide. The toxicity of organic mercury includes damage to the central nervous system of anorexia, ataxia, dismetria, eye disorders, blindness, convulsive hearing loss, degeneration and necrosis, neurons and coma and death.

\section{CONCLUSION}

1. The diversity of medicinal plants in the study sites has a low level of stability of species diversity.

2. The content of metal elements $\mathrm{Mn}, \mathrm{As}$, and $\mathrm{Hg}$ on medicinal plants in the study sites has exceeded the threshold.

3. Mn, US, and $\mathrm{Hg}$ metals contents cause health problems in humans.

\section{REFERENCES}

Absissalam R., S. Bronto, A. Harijoko, dan A. Hendratno. 2009. Identifikasi Gunungapi Purba Karangtengah di Pegunungan Selatan, Wonogiri, Jawa Tengah. Jurnal Geologi Insonesia, Vol 4 (4):253-267.

Agustina, D.K. 2008. Studi Vegetasi di Hutan Lindung RPH Donomulyo BK PH Sengguruh KPH Malang. Skripsi tidak diterbitkan. Malang: Jurusan Biologi Fakultas Saintek UIN Mau-lana Malik Ibrahim.

Alloway. 1990. Soil Processes and Behaviour of Metals. In Alloway (Ed). Heavy Mettals in Soils. New York. Blackie Glasgow and London Halsted Press. John Wiley and Sons,Inc.

Alloway, B.J and Ayres, D.C. 1995. Chemical Principle of Environmental Pollution, 2nd Edition, London. Blackie Academic and Professional, Chapman \& Hall.

Arrijani. 2008. Struktur dan komposisi vegetasi zona montana TamanNasional Gunung Gede Pangrango. Biodiversitas 9 (2): 134-141.

Fardiaz, S. 1992. Polusi Air dan Udara. Yoyakarta. Kanisius.

Hardiani, Henggar. 2009. Potensi Tanaman Dalam Mengakumulasi Logam CuPada Media Tanah Terkontaminasi Limbah Padat Industri Kertas. Jurnal BS. Vol: 44(1): 27- 40

Maryantika, N., Lalu, M.J., Andie, S. 2010. Analisa Perubahan Vegetasi Ditinjau dari Tingkat Ketinggian dan Kemiringan Lahan Menggunakan Citra Satelit Landsat dan Spot 4 (Studi Kasus di Kabupaten Pasuru-han). (Online), (reposi tory.its.ac.id/ bitstream/...pdf) Diakses pada 30 Maret 2013.

Mirdat, Yosep S Patádungan, Isrun. 2013. The Level Of Heavy Metal OfMercury (Hg) In Soil Of AgriculturalArea round. Gold Mining In Poboya, Palu. e-J. Agrotekbis 1 (2) : 127-134.

Putranto, T. T. 2011. Pencemaran 
Tanah. Teknik. Vol. 32, No. 11. Hal: 62-71

Setiabudi, B.T. 2005. Penyebaran Merkuri Akibat Usaha Pertambangan Emas Di Daerah Sangon. D.I Yogyakarta. Kabupaten Kulon Progo.

Steinnes, E. 1990.Mercury. In B.J.Alloway (ed). Heavy Metals in Soil. Blackie Glasgow and London Halsted Press. New York. John Wiley, Sons Inc

Suproborini, A. 2017. Dampak Penambangan Emas Rakyat Terhadap Kandungan Hg Tanah, Air, Tanaman, Struktur dan Komposisi Vegetasi Di Dusun Mesu Desa Boto Kecamatan Jatiroto Kabupaten Wonogiri. Tesis. Surakarta.Pascasarjana Universitas Sebelas Maret.

Susanto, W. 2012. Analisis Vegetasi pada Ekosistem Hutan Hujan Tropis untuk Pengelolaan Kawasan Taman Hutan Raya, Raden Soerjo Wilayah Pengelolaan Cangar-Kota Batu).(online), 30/ 03/2013

Syafei. 1990. Dinamika Populasi. Kajian Ekologi Kuantitatif. Jakarta: Pustaka Sinar Harapan

Widowati W, Sastiono A, Jusuf R. 2008. Efek Toksik Logam:Pencegahan dan Penanggulangan Pencemaran. Yogyakarta. Andi Offset .

Widyati. 2011. Potensi Tumbuhan Bawah Sebagai Akumulator Logam Berat Untuk Membantu Rehabilitasi lahan Bekas Tambang .Jurnal Mitra Hutan Tanaman Vol: 6 (2): 46-56. 